\title{
Kangiella geojedonensis sp. nov., isolated from seawater
}

\author{
Jung-Hoon Yoon, ${ }^{1,2}$ So-Jung Kang, ${ }^{2}$ Soo-Young Lee, ${ }^{2}$ Jung-Sook Lee ${ }^{2}$ \\ and Tae-Kwang $\mathrm{Oh}^{2}$
}

Correspondence

Jung-Hoon Yoon

jhyoon69@skku.edu
The genus Kangiella was first proposed by Yoon et al. (2004) with the description of two novel species, Kangiella koreensis and Kangiella aquimarina. Subsequently, two further Kangiella species with validly published names, Kangiella japonica (Romanenko et al., 2010) and Kangiella spongicola (Ahn et al., 2011), have been described. Phylogenetic analysis based on 16S rRNA gene sequences showed that the genus Kangiella belongs to the Gammaproteobacteria (Yoon et al., 2004). Members of the genus Kangiella have been isolated from marine environments (Yoon et al., 2004; Romanenko et al., 2010). In this study, we describe a bacterial strain, designated YCS- $5^{\mathrm{T}}$, which was isolated from seawater off the southern coast of Korea. Comparative 16S rRNA gene sequence analysis indicated that strain YCS $-5^{\mathrm{T}}$ can be affiliated to the genus Kangiella. The aim of the present work was to determine the exact taxonomic position of strain YCS- $5^{\mathrm{T}}$ by using a polyphasic approach that included the determination of chemotaxonomic and phenotypic properties and detailed phylogenetic investigations based on 16S rRNA gene sequences.

The GenBank/EMBL/DDBJ accession number for the $16 \mathrm{~S}$ rRNA gene sequence of strain YCS-5 $5^{\top}$ is HO340606.

A supplementary figure is available with the online version of this paper.
Strain YCS $-5^{\mathrm{T}}$ was isolated by the standard dilution plating technique on marine agar 2216 (MA; Difco) at $25^{\circ} \mathrm{C}$. K. koreensis (type species of the genus Kangiella) SW- $-125^{\mathrm{T}}$, which was used as a reference strain for polar lipid analysis, was obtained from our previous study (Yoon et al., 2004). K. japonica JCM $16211^{\mathrm{T}}$, which was used as a reference strain for DNA-DNA hybridization, was obtained from the Japan Collection of Microorganisms, Saitama, Japan. The morphological, physiological and biochemical characteristics of strain YCS $-5^{\mathrm{T}}$ were investigated using cells that were routinely cultivated on MA at $30{ }^{\circ} \mathrm{C}$. Cell morphology was examined by using light microscopy (DP70; Olympus) and transmission electron microscopy (CM-20; Philips). Flagellation was determined by transmission electron microscopy of cells from an exponentially growing culture. For this purpose, cells were negatively stained with $1 \%(\mathrm{w} / \mathrm{v})$ phosphotungstic acid and grids were examined after being air-dried. The Gram reaction was determined by using the bioMérieux Gram stain kit according to the manufacturer's instructions. Growth in the absence of $\mathrm{NaCl}$ and in the presence of $0.5,1.0,2.0$ and $3.0 \%(\mathrm{w} / \mathrm{v}) \mathrm{NaCl}$ was investigated by using trypticase soy broth prepared according to the formula of the Difco medium except that $\mathrm{NaCl}$ 
was excluded and that $0.45 \%(\mathrm{w} / \mathrm{v}) \mathrm{MgCl}_{2} \cdot 6 \mathrm{H}_{2} \mathrm{O}$ or $0.06 \%$ $(\mathrm{w} / \mathrm{v}) \mathrm{KCl}$ was added. Growth at various $\mathrm{NaCl}$ concentrations $(2.0-18.0 \%, \mathrm{w} / \mathrm{v}$, in increments of $1.0 \%)$ was investigated in marine broth 2216 (MB; Difco). Growth at various temperatures $\left(4,10,20,25,28,30,35,37,40\right.$ and $\left.45^{\circ} \mathrm{C}\right)$ was measured on MA. The $\mathrm{pH}$ range for growth was determined in $\mathrm{MB}$ adjusted to various $\mathrm{pH}$ values ( $\mathrm{pH}$ 4.5-9.5, in increments of $0.5 \mathrm{pH}$ unit) by the addition of $\mathrm{HCl}$ or $\mathrm{Na}_{2} \mathrm{CO}_{3} ; \mathrm{pH}$ values were verified after autoclaving. Growth under anaerobic conditions was determined after incubation in a Forma anaerobic chamber on MA and on MA supplemented with potassium nitrate $(0.1 \%, \mathrm{w} / \mathrm{v})$, both of which had been prepared anaerobically under a nitrogen atmosphere. Catalase and oxidase activities were determined as described by Cowan \& Steel (1965). Hydrolysis of casein, starch, hypoxanthine, tyrosine and xanthine was tested on MA using the substrate concentrations described by Cowan \& Steel (1965). Hydrolysis of aesculin, gelatin, Tweens 20, 40, 60 and 80 , and urea and nitrate reduction were investigated as described previously (Lányí, 1987) with the modification that artificial seawater was used for preparation of media. The artificial seawater contained $\left(1^{-1}\right.$ distilled water) $23.6 \mathrm{~g} \mathrm{NaCl}$, $0.64 \mathrm{~g} \mathrm{KCl}, 4.53 \mathrm{~g} \mathrm{MgCl}_{2} .6 \mathrm{H}_{2} \mathrm{O}, 5.94 \mathrm{~g} \mathrm{MgSO}_{4} .7 \mathrm{H}_{2} \mathrm{O}$ and $1.3 \mathrm{~g} \mathrm{CaCl}_{2} \cdot 2 \mathrm{H}_{2} \mathrm{O}$ (Bruns et al., 2001). Acid production from carbohydrates was determined as described by Leifson (1963). Susceptibility to antibiotics was tested on MA plates using antibiotic discs of the following: ampicillin $(10 \mu \mathrm{g})$, chloramphenicol $(100 \mu \mathrm{g})$, penicillin $\mathrm{G}(20 \mathrm{U})$, polymyxin B $(100 \mathrm{U})$, streptomycin $(50 \mu \mathrm{g})$ and tetracycline $(30 \mu \mathrm{g})$. Other physiological and biochemical tests were performed with the API 20E and API ZYM systems (bioMérieux).

Cell biomass of strain YCS- $5^{\mathrm{T}}$ for DNA extraction and for the analyses of isoprenoid quinones and polar lipids was obtained from cultures grown for 5 days in $\mathrm{MB}$ at $30^{\circ} \mathrm{C}$. Cell biomass of $K$. koreensis SW $-125^{\mathrm{T}}$ for polar lipid analysis and cell biomass of $K$. japonica JCM $16211^{\mathrm{T}}$ for DNA extraction were obtained from cultures grown for 5 days in $\mathrm{MB}$ at $30^{\circ} \mathrm{C}$. Chromosomal DNA was isolated and purified as described previously (Yoon et al., 1996), with the exception that RNase T1 was used in combination with RNase A to minimize contamination with RNA. The $16 \mathrm{~S}$ rRNA gene was amplified by PCR using two universal primers as described previously (Yoon et al., 1998). Sequencing of the amplified 16S rRNA gene and phylogenetic analysis were performed as described by Yoon et al. (2004). Isoprenoid quinones were extracted according to the method of Komagata \& Suzuki (1987) and analysed using reversed-phase HPLC and a YMC ODS-A $(250 \times 4.6 \mathrm{~mm})$ column. For fatty acid methyl ester analysis, cell mass of strain YCS $-5^{\mathrm{T}}$ was harvested from MA plates after incubation for 7 days at $30{ }^{\circ} \mathrm{C}$. Fatty acids were saponified, methylated and extracted using the standard protocol of the MIDI (Sherlock Microbial Identification System, version 4.0). Fatty acids were analysed by GC (Hewlett Packard 6890) and identified by using the TSBA40 database of the Microbial Identification System (Sasser, 1990). Polar lipids were extracted according to the procedures described by Minnikin et al. (1984) and identified by two-dimensional TLC followed by spraying with molybdophosphoric acid, molybdenum blue, ninhydrin and $\alpha$-naphthol reagents (Minnikin et al., 1984; Komagata \& Suzuki, 1987) and Dragendorffs reagent (Sigma). The DNA G $+\mathrm{C}$ content was determined by the method of Tamaoka \& Komagata (1984) with the modification that DNA was hydrolysed and the resultant nucleotides were analysed by reversed-phase HPLC. DNA-DNA hybridization was performed fluorometrically at $45{ }^{\circ} \mathrm{C}$ by the method of Ezaki et al. (1989) using photobiotin-labelled DNA probes and microdilution wells. Hybridization was performed with five replications for each sample. The highest and lowest values obtained for each sample were excluded and the means of the remaining three values are quoted as DNA-DNA relatedness values.

Morphological, cultural, physiological and biochemical characteristics of strain YCS $-5^{\mathrm{T}}$ are given in the species description (see below) or in Table 1. The almost complete 16S rRNA gene sequence of strain YCS $-5^{\mathrm{T}}$ determined in this study comprised $1461 \mathrm{nt}$ (approx. $96 \%$ of the Escherichia coli $16 \mathrm{~S}$ rRNA sequence). In the neighbour-joining phylogenetic

Table 1. Differential phenotypic characteristics of Kangiella geojedonensis YCS $-5^{\top}$ and the type strains of three Kangiella species

Strains: 1, K. geojedonensis YCS- $5^{\mathrm{T}} ; 2, K$. koreensis SW-125 $5^{\mathrm{T}} ; 3, \mathrm{~K}$. aquimarina SW-154 ${ }^{\mathrm{T}}$; 4, K. japonica KMM $3899^{\mathrm{T}}$. Data for reference strains are from Yoon et al. (2004) and Romanenko et al. (2010). All strains are Gram-stain-negative and rod-shaped. All strains are positive for catalase, oxidase, hydrolysis of casein, gelatin, tyrosine and Tweens 20, 40 and 80, activity of esterase lipase (C8), leucine arylamidase and naphthol-AS-BI-phosphohydrolase (weak for $K$. japonica $\mathrm{KMM} 3899^{\mathrm{T}}$ ), and susceptibility to chloramphenicol and polymyxin B. All strains are negative for motility, nitrate reduction (under aerobic conditions), $\mathrm{H}_{2} \mathrm{~S}$ and indole production, hydrolysis of aesculin and starch, activity of lipase (C14), cystine arylamidase, $\alpha$ chymotrypsin, $\alpha$-galactosidase, $\beta$-galactosidase, $\beta$-glucuronidase, $\alpha$ glucosidase, $\beta$-glucosidase, $N$-acetyl- $\beta$-glucosaminidase, $\alpha$-mannosidase and $\alpha$-fucosidase, and susceptibility to tetracycline.

\begin{tabular}{|lcccc|}
\hline Characteristic & $\mathbf{1}$ & $\mathbf{2}$ & $\mathbf{3}$ & $\mathbf{4}$ \\
\hline Growth at/in: & & & & \\
$4{ }^{\circ} \mathrm{C}$ & - & + & - & + \\
$45{ }^{\circ} \mathrm{C}$ & - & - & + & - \\
$15 \%(\mathrm{w} / \mathrm{v}) \mathrm{NaCl}$ & + & - & - & - \\
Enzyme activity (API ZYM) & & & & \\
Alkaline phosphatase & + & + & + & - \\
Esterase (C4) & + & + & + & - \\
Valine arylamidase & - & + & + & + \\
Trypsin & - & + & + & - \\
Acid phosphatase & + & - & + & - \\
Susceptibility to antibiotics & & & & \\
Ampicillin & - & + & + & + \\
Penicillin G & - & + & + & + \\
Streptomycin & - & + & + & + \\
DNA G + C content (mol\%) & 47 & 44 & 44 & 45.8 \\
\end{tabular}


tree based on 16S rRNA gene sequences, strain YCS- $5^{\mathrm{T}}$ fell within the clade comprising Kangiella species, clustering coherently with $K$. japonica KMM $3899^{\mathrm{T}}$ and K. spongicola $\mathrm{A} 79^{\mathrm{T}}$ (Fig. 1). This cluster also joined the cluster comprising the type strains of $K$. koreensis and $K$. aquimarina with a bootstrap resampling value of $100 \%$ (Fig. 1). Strain YCS- $5^{\mathrm{T}}$ exhibited 16S rRNA gene sequence similarity values of 96.6 , 95.7 and $97.9 \%$ to the type strains of $K$. koreensis, $K$. aquimarina and K. japonica, respectively, and less than $89.8 \%$ to strains of other species used in the phylogenetic analysis.

The predominant isoprenoid quinone detected in strain YCS $-5^{\mathrm{T}}$ was ubiquinone- $8(\mathrm{Q}-8)$, which is the same as that found in members of the genus Kangiella (Yoon et al., 2004; Romanenko et al., 2010). The cellular fatty acid profile of strain YCS $-5^{\mathrm{T}}$ is shown in Table 2, together with those of type strains of two Kangiella species that were analysed under identical conditions and using the same methods (Yoon et al., 2004). The major fatty acids ( $>10 \%$ of total fatty acids) detected in strain YCS $-5^{\mathrm{T}}$ were iso- $\mathrm{C}_{17: 0}$, iso- $\mathrm{C}_{15: 0}$, iso- $\mathrm{C}_{11: 0}$ $3-\mathrm{OH}$ and iso- $\mathrm{C}_{17: 1} \omega 9 c$ (Table 2). The fatty acid profile of strain YCS $-5^{\mathrm{T}}$ was similar to those of $K$. koreensis SW $-125^{\mathrm{T}}$ and $K$. aquimarina $\mathrm{SW}-154^{\mathrm{T}}$, even though there were differences in the proportions of some fatty acids, particularly iso- $\mathrm{C}_{17: 0}$ and iso- $\mathrm{C}_{15: 0}$ (Table 2). The major polar lipids detected in strain YCS $-5^{\mathrm{T}}$ were phosphatidylglycerol and an unidentified aminolipid (Supplementary Fig. S1, available in IJSEM Online). This polar lipid profile was similar to that of K. koreensis $\mathrm{SW}-125^{\mathrm{T}}$ although phosphatidylethanolamine and phosphatidylmonomethylethanolamine, which were detected as major components in $K$. koreensis $\mathrm{SW}-125^{\mathrm{T}}$, were minor components in strain YCS $-5^{\mathrm{T}}$. The DNA G+C content of strain YCS $-5^{\mathrm{T}}$ was $47 \mathrm{~mol} \%$. The results obtained from chemotaxonomic analyses, which showed that the isolate shared similar properties to Kangiella species, were in agreement with the results of phylogenetic analysis, i.e. that strain YCS $-5^{\mathrm{T}}$ belongs to the genus Kangiella (Yoon et al., 2004; Romanenko et al., 2010).
Strain YCS $-5^{\mathrm{T}}$ exhibited a mean DNA-DNA relatedness value of $12 \%$ to K. japonica JCM $16211^{\mathrm{T}}$. Strain YCS-5 ${ }^{\mathrm{T}}$ was distinguishable from Kangiella species by differences in several phenotypic characteristics, most of which were determined under the same conditions and using the same methods (Table 1). The phylogenetic and genetic distinctiveness of strain YCS- $5^{\mathrm{T}}$, together with its differential phenotypic properties, are sufficient to show that this strain is separate from other Kangiella species (Stackebrandt \& Goebel, 1994; Wayne et al., 1987). Therefore, on the basis of the phenotypic, chemotaxonomic and phylogenetic data, strain YCS $-5^{\mathrm{T}}$ is considered to represent a novel species of the genus Kangiella, for which the name Kangiella geojedonensis sp. nov. is proposed.

\section{Description of Kangiella geojedonensis sp. nov.}

Kangiella geojedonensis (geo.je.do.nen'sis. N.L. fem. adj. geojedonensis pertaining to Geojedo, the Korean island where the type strain was isolated).

Cells are Gram-stain-negative, non-spore-forming, nonflagellated rods $(0.2-0.4 \times 0.8-6.5 \mu \mathrm{m})$. Colonies on MA are circular to irregular, flat, smooth, glistening, greyishyellow in colour and $3.0-5.0 \mathrm{~mm}$ in diameter after incubation for 7 days at $30{ }^{\circ} \mathrm{C}$. Optimal growth occurs at $30{ }^{\circ} \mathrm{C}$; growth occurs at 10 and $40{ }^{\circ} \mathrm{C}$, but not at 4 or $45{ }^{\circ} \mathrm{C}$. Optimal $\mathrm{pH}$ for growth is between 7.0 and 7.5; growth occurs at $\mathrm{pH} 5.5$, but not at $\mathrm{pH}$ 5.0. Optimal growth occurs in the presence of $2 \%(\mathrm{w} / \mathrm{v}) \mathrm{NaCl}$; growth occurs at $0.5-16.0 \%(\mathrm{w} / \mathrm{v}) \mathrm{NaCl} . \mathrm{Mg}^{2+}$ ions are required for growth. Growth does not occur under anaerobic conditions on MA or on MA supplemented with nitrate. Catalase- and oxidase-positive. Nitrate reduction is negative. Casein, gelatin, tyrosine, and Tweens 20, 40, 60 and 80 are hydrolysed, but aesculin, hypoxanthine, starch and xanthine are not. Acid is not produced from L-arabinose, cellobiose, D-fructose, D-galactose, D-glucose, myo-inositol, lactose, maltose, D-mannitol, D-mannose, melezitose,

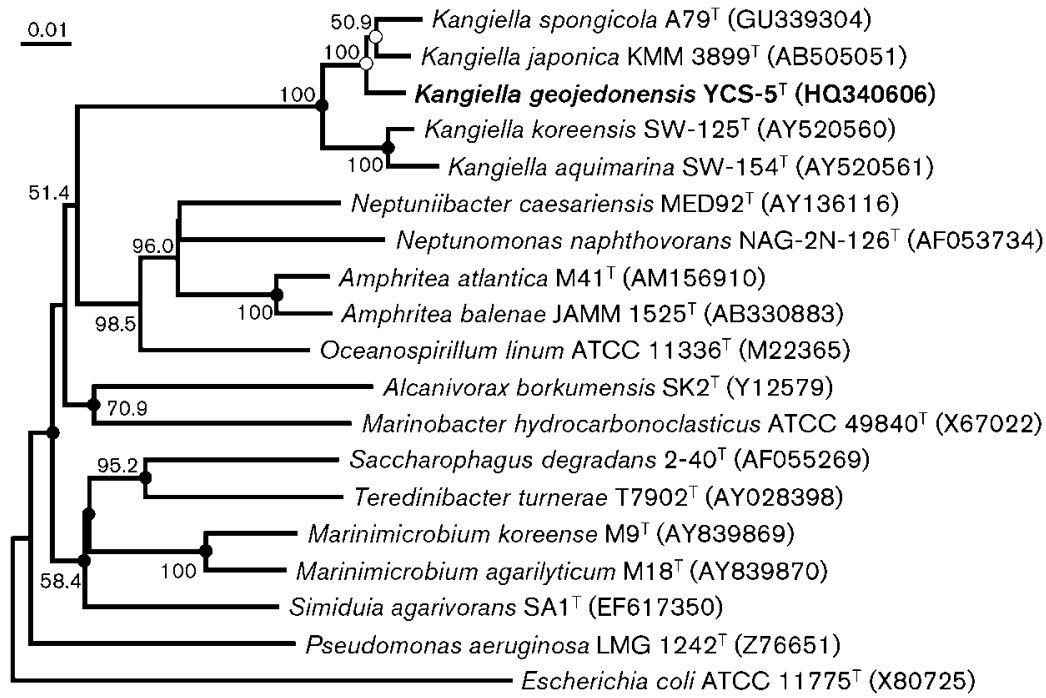

Fig. 1. Neighbour-joining phylogenetic tree based on 16S rRNA gene sequences showing the positions of Kangiella geojedonensis YCS- $5^{\top}$ and strains of other Kangiella species and some other related taxa. Bootstrap values (expressed as percentages of 1000 replications) $>50 \%$ are shown at branching points. Filled circles indicate that the corresponding nodes were also recovered in the trees generated with the maximum-likelihood and maximum-parsimony algorithms. Open circles indicate that the corresponding nodes were also recovered in the tree generated with the maximum-likelihood algorithm. Escherichia coli ATCC $11775^{\top}$ (accession no. X80725) was used as an outgroup. Bar, 0.01 substitutions per nucleotide position. 
Table 2. Cellular fatty acid compositions (\%) of Kangiella geojedonensis YCS- $5^{\top}$ and the type strains of three Kangiella species

Strains: 1, K. geojedonensis $\mathrm{YCS}-5^{\mathrm{T}} ; 2, K$. koreensis SW-125 $5^{\mathrm{T}} ; 3, \mathrm{~K}$. aquimarina SW-154 $4^{\mathrm{T}} ; 4, \mathrm{~K}$. japonica KMM $3899^{\mathrm{T}}$. Data for reference strains are from Yoon et al. (2004) and Romanenko et al. (2010). Fatty acids that represented $<0.5 \%$ in all strains were omitted. -, Not detected or $<0.5 \%$.

\begin{tabular}{|c|c|c|c|c|}
\hline Fatty acid & 1 & 2 & 3 & 4 \\
\hline \multicolumn{5}{|c|}{ Straight-chain fatty acid } \\
\hline $\mathrm{C}_{16: 0}$ & 3.0 & 1.1 & 1.6 & 3.9 \\
\hline \multicolumn{5}{|c|}{ Branched fatty acid } \\
\hline iso- $\mathrm{C}_{11: 0}$ & 6.7 & 5.6 & 6.5 & 4.7 \\
\hline iso- $\mathrm{C}_{13: 0}$ & 0.3 & 0.4 & 0.6 & - \\
\hline iso- $\mathrm{C}_{15: 0}$ & 21.4 & 57.6 & 50.7 & 26.9 \\
\hline iso- $\mathrm{C}_{15: 1}$ & 0.5 & 1.2 & 1.1 & 6.9 \\
\hline iso- $\mathrm{C}_{16: 0}$ & 1.6 & 0.7 & 1.0 & - \\
\hline iso- $\mathrm{C}_{17: 0}$ & 28.8 & 7.2 & 11.0 & 23.8 \\
\hline iso- $\mathrm{C}_{17: 1} \omega 9 c$ & 10.9 & 8.6 & 7.0 & 12.7 \\
\hline \multicolumn{5}{|c|}{ Hydroxy fatty acid } \\
\hline iso- $\mathrm{C}_{11: 0} 3-\mathrm{OH}$ & 13.0 & 10.5 & 11.7 & 13.6 \\
\hline iso- $\mathrm{C}_{15: 0} 3-\mathrm{OH}$ & 0.9 & 0.9 & 0.7 & - \\
\hline iso- $\mathrm{C}_{17: 0} 3-\mathrm{OH}$ & 3.4 & 1.0 & 0.6 & - \\
\hline \multicolumn{5}{|c|}{ Summed features ${ }^{\star}$} \\
\hline 1 & 5.2 & 3.2 & 4.0 & - \\
\hline 3 & 0.9 & - & - & - \\
\hline \multicolumn{5}{|c|}{ Unknown fatty acid $\dagger$} \\
\hline ECL 13.565 & 0.8 & - & - & - \\
\hline
\end{tabular}

${ }^{*}$ Summed features represent groups of two or three fatty acids that cannot be separated by GLC with the MIDI system. Summed feature 1 contained $\mathrm{C}_{13: 0} 3-\mathrm{OH}$ and/or iso- $\mathrm{C}_{15: 1}$. Summed feature 3 contained $\mathrm{C}_{16: 1} \omega 7 c$ and/or iso- $\mathrm{C}_{15: 0} 2-\mathrm{OH}$.

$\dagger \mathrm{ECL}$, Equivalent chain-length.

melibiose, raffinose, L-rhamnose, D-ribose, D-sorbitol, sucrose, trehalose or D-xylose. The predominant ubiquinone is Q-8. The major fatty acids $(>10 \%$ of total fatty acids) are iso- $\mathrm{C}_{17: 0}$, iso- $\mathrm{C}_{15: 0}$, iso- $\mathrm{C}_{11: 0} 3-\mathrm{OH}$ and iso$\mathrm{C}_{17: 1} \omega 9 c$. The major polar lipids are phosphatidylglycerol and an unidentified aminolipid. Other phenotypic properties are shown in Table 1.

The type strain, YCS $-5^{\mathrm{T}} \quad\left(=\mathrm{KCTC} \quad 23420^{\mathrm{T}}=\mathrm{CCUG}\right.$ $60526^{\mathrm{T}}$ ), was isolated from seawater off Geojedo in the South Sea, Korea. The DNA G+C content of the type strain is $47 \mathrm{~mol} \%$ (HPLC).

\section{Acknowledgements}

This work was supported by the Program for Collection, Management and Utilization of Biological Resources (grant M10867010003) and the 21C Frontier Program of Microbial Genomics and Applications (grant 11-2008-00-002-00) from the Ministry of Education, Science and Technology (MEST) of the Republic of Korea.

\section{References}

Ahn, J., Park, J.-W., McConnell, J. A., Ahn, Y.-B. \& Häggblom, M. M. (2011). Kangiella spongicola sp. nov., a halophilic marine bacterium isolated from the marine sponge Chondrilla nucula. Int J Syst Evol Microbiol 61, 961-964.

Bruns, A., Rohde, M. \& Berthe-Corti, L. (2001). Muricauda ruestringensis gen. nov., sp. nov., a facultatively anaerobic, appendaged bacterium from German North Sea intertidal sediment. Int J Syst Evol Microbiol 51, 1997-2006.

Cowan, S. T. \& Steel, K. J. (1965). Manual for the Identification of Medical Bacteria. London: Cambridge University Press.

Ezaki, T., Hashimoto, Y. \& Yabuuchi, E. (1989). Fluorometric deoxyribonucleic acid-deoxyribonucleic acid hybridization in microdilution wells as an alternative to membrane filter hybridization in which radioisotopes are used to determine genetic relatedness among bacterial strains. Int J Syst Bacteriol 39, 224-229.

Komagata, K. \& Suzuki, K. (1987). Lipid and cell-wall analysis in bacterial systematics. Methods Microbiol 19, 161-207.

Lányí, B. (1987). Classical and rapid identification methods for medically important bacteria. Methods Microbiol 19, 1-67.

Leifson, E. (1963). Determination of carbohydrate metabolism of marine bacteria. J Bacteriol 85, 1183-1184.

Minnikin, D. E., O'Donnell, A. G., Goodfellow, M., Alderson, G., Athalye, M., Schaal, A. \& Parlett, J. H. (1984). An integrated procedure for the extraction of bacterial isoprenoid quinones and polar lipids. J Microbiol Methods 2, 233-241.

Romanenko, L. A., Tanaka, N., Frolova, G. M. \& Mikhailov, V. V. (2010). Kangiella japonica sp. nov., isolated from a marine environment. Int J Syst Evol Microbiol 60, 2583-2586.

Sasser, M. (1990). Identification of bacteria by gas chromatography of cellular fatty acids, MIDI Technical Note 101. Newark, DE: MIDI Inc.

Stackebrandt, E. \& Goebel, B. M. (1994). Taxonomic note: a place for DNA-DNA reassociation and $16 \mathrm{~S}$ rRNA sequence analysis in the present species definition in bacteriology. Int J Syst Bacteriol 44, 846849.

Tamaoka, J. \& Komagata, K. (1984). Determination of DNA base composition by reverse-phase high-performance liquid chromatography. FEMS Microbiol Lett 25, 125-128.

Wayne, L. G., Brenner, D. J., Colwell, R. R., Grimont, P. A. D., Kandler, O., Krichevsky, M. I., Moore, L. H., Moore, W. E. C., Murray, R. G. E. \& other authors (1987). International Committee on Systematic Bacteriology. Report of the ad hoc committee on reconciliation of approaches to bacterial systematics. Int J Syst Bacteriol 37, 463-464.

Yoon, J.-H., Kim, H., Kim, S.-B., Kim, H.-J., Kim, W. Y., Lee, S. T., Goodfellow, M. \& Park, Y.-H. (1996). Identification of Saccharomonospora strains by the use of genomic DNA fragments and rRNA gene probes. Int J Syst Bacteriol 46, 502-505.

Yoon, J.-H., Lee, S. T. \& Park, Y.-H. (1998). Inter- and intraspecific phylogenetic analysis of the genus Nocardioides and related taxa based on 16S rDNA sequences. Int J Syst Bacteriol 48, 187-194.

Yoon, J.-H., Oh, T.-K. \& Park, Y.-H. (2004). Kangiella koreensis gen. nov., sp. nov. and Kangiella aquimarina sp. nov., isolated from a tidal flat of the Yellow Sea in Korea. Int J Syst Evol Microbiol 54, 1829-1835. 